\title{
Active Combustion Control for Aircraft Gas-Turbine Engines-Experimental Results for an Advanced, Low-Emissions Combustor Prototype
}

John C. DeLaat, George Kopasakis, Joseph R. Saus, and Clarence T. Chang Glenn Research Center, Cleveland, Ohio

Changlie Wey

ASRC Aerospace Corporation, Cleveland, Ohio 


\section{NASA STI Program . . . in Profile}

Since its founding, NASA has been dedicated to the advancement of aeronautics and space science. The NASA Scientific and Technical Information (STI) program plays a key part in helping NASA maintain this important role.

The NASA STI Program operates under the auspices of the Agency Chief Information Officer. It collects, organizes, provides for archiving, and disseminates NASA's STI. The NASA STI program provides access to the NASA Aeronautics and Space Database and its public interface, the NASA Technical Reports Server, thus providing one of the largest collections of aeronautical and space science STI in the world. Results are published in both non-NASA channels and by NASA in the NASA STI Report Series, which includes the following report types:

- TECHNICAL PUBLICATION. Reports of completed research or a major significant phase of research that present the results of NASA programs and include extensive data or theoretical analysis. Includes compilations of significant scientific and technical data and information deemed to be of continuing reference value. NASA counterpart of peer-reviewed formal professional papers but has less stringent limitations on manuscript length and extent of graphic presentations.

- TECHNICAL MEMORANDUM. Scientific and technical findings that are preliminary or of specialized interest, e.g., quick release reports, working papers, and bibliographies that contain minimal annotation. Does not contain extensive analysis.

- CONTRACTOR REPORT. Scientific and technical findings by NASA-sponsored contractors and grantees.
- CONFERENCE PUBLICATION. Collected papers from scientific and technical conferences, symposia, seminars, or other meetings sponsored or cosponsored by NASA.

- SPECIAL PUBLICATION. Scientific, technical, or historical information from NASA programs, projects, and missions, often concerned with subjects having substantial public interest.

- TECHNICAL TRANSLATION. Englishlanguage translations of foreign scientific and technical material pertinent to NASA's mission.

Specialized services also include creating custom thesauri, building customized databases, organizing and publishing research results.

For more information about the NASA STI program, see the following:

- Access the NASA STI program home page at http://www.sti.nasa.gov

- E-mail your question to help@sti.nasa.gov

- Fax your question to the NASA STI Information Desk at 443-757-5803

- Phone the NASA STI Information Desk at 443-757-5802

- Write to: STI Information Desk NASA Center for AeroSpace Information 7115 Standard Drive Hanover, MD 21076-1320 


\section{Active Combustion Control for Aircraft Gas-Turbine Engines-Experimental Results for an Advanced, Low-Emissions Combustor Prototype}

John C. DeLaat, George Kopasakis, Joseph R. Saus, and Clarence T. Chang Glenn Research Center, Cleveland, Ohio

Changlie Wey

ASRC Aerospace Corporation, Cleveland, Ohio

Prepared for the

50th Aerospace Sciences Meeting

sponsored by the American Institute of Aeronautics and Astronautics

Nashville, Tennessee, January 9-12, 2012

National Aeronautics and

Space Administration

Glenn Research Center

Cleveland, Ohio 44135 


\section{Acknowledgments}

The authors would like to thank Dr. Daniel Paxson for his invaluable insights concerning the phenomenon of combustion instability. The authors would also like to thank the staff of Test Cell CE5 at NASA Glenn Research Center for their excellence in conducting the experimental part of this effort. Finally, the authors thank the NASA Fundamental Aeronautics Supersonics Project and the Environmentally Responsive Aircraft Project for supporting this work.

Trade names and trademarks are used in this report for identification only. Their usage does not constitute an official endorsement, either expressed or implied, by the National Aeronautics and Space Administration.

This work was sponsored by the Fundamental Aeronautics Program at the NASA Glenn Research Center.

Level of Review: This material has been technically reviewed by technical management.

Available from

NASA Center for Aerospace Information 7115 Standard Drive

Hanover, MD 21076-1320
National Technical Information Service 5301 Shawnee Road Alexandria, VA 22312

Available electronically at http://www.sti.nasa.gov 


\title{
Active Combustion Control for Aircraft Gas-Turbine Engines- Experimental Results for an Advanced, Low-Emissions Combustor Prototype
}

\author{
John C. DeLaat, George Kopasakis, Joseph R. Saus, and Clarence T. Chang \\ National Aeronautics and Space Administration \\ Glenn Research Center \\ Cleveland, Ohio 44135 \\ Changlie Wey \\ ASRC Aerospace Corporation \\ Cleveland, Ohio 44135
}

\begin{abstract}
Lean combustion concepts for aircraft engine combustors are prone to combustion instabilities. Mitigation of instabilities is an enabling technology for these low-emissions combustors. NASA Glenn Research Center's prior activity has demonstrated active control to suppress a high-frequency combustion instability in a combustor rig designed to emulate an actual aircraft engine instability experience with a conventional, rich-front-end combustor. The current effort is developing further understanding of the problem specifically as applied to future lean-burning, very low-emissions combustors. A prototype advanced, low-emissions aircraft engine combustor with a combustion instability has been identified and previous work has characterized the dynamic behavior of that combustor prototype. The combustor exhibits thermoacoustic instabilities that are related to increasing fuel flow and that potentially prevent full-power operation. A simplified, non-linear oscillator model and a more physics-based sectored 1-D dynamic model have been developed to capture the combustor prototype's instability behavior. Utilizing these models, the NASA Adaptive Sliding Phasor Average Control (ASPAC) instability control method has been updated for the low-emissions combustor prototype. Active combustion instability suppression using the ASPAC control method has been demonstrated experimentally with this combustor prototype in a NASA combustion test cell operating at engine pressures, temperatures, and flows. A high-frequency fuel valve was utilized to perturb the combustor fuel flow. Successful instability suppression was shown using a dynamic pressure sensor in the combustor for controller feedback. Instability control was also shown with a pressure feedback sensor in the lower temperature region upstream of the combustor. It was also demonstrated that the controller can prevent the instability from occurring while combustor operation was transitioning from a stable, low-power condition to a normally unstable high-power condition, thus enabling the high-power condition.
\end{abstract}

\section{Nomenclature}

$\begin{array}{ll}\text { ASPAC } & \text { Adaptive Sliding Phasor Average Control } \\ \text { FAR } & \text { Fuel/Air Ratio } \\ \dot{m} & \text { Mass flow } \\ P & \text { Pressure } \\ P_{3} & \text { Combustor inlet pressure } \\ P_{3 \text { DynA }} & \text { Sensed dynamic combustor inlet pressure, first location } \\ P_{3 \text { DynB }} & \text { Sensed dynamic combustor inlet pressure, second location } \\ P_{4} & \text { Combustor pressure } \\ P_{4 \text { Dynup }} & \text { Sensed dynamic combustor pressure, upstream location } \\ P_{4 \text { DynDn }} & \text { Sensed dynamic combustor pressure, downstream location }\end{array}$




$\begin{array}{ll}T & \text { Temperature } \\ T_{3} & \text { Combustor inlet temperature } \\ \phi & \text { Equivalence ratio }\end{array}$

\section{Introduction}

Future aircraft engines must provide low emissions and high efficiency at low cost while maintaining the reliability and operability of present day engines. The demands for increased performance and decreased emissions have resulted in advanced combustor designs that are critically dependent on efficient fuel/air mixing and lean operation. However, all combustors, but most notably lean-burning ultra-low-emissions combustors, are susceptible to combustion instabilities. These instabilities are typically caused by the interaction of the fluctuating heat release of the combustion process with naturally occurring acoustic resonances (Refs. 1 and 2). If not mitigated, these interactions can produce large, highfrequency pressure oscillations within the combustor that could reduce component life and potentially lead to premature mechanical failures.

Combustion instability has been a persistent issue in ground-based gas turbines using premixed combustors (Refs. 3 and 4) and will become more challenging as aero-engine combustor development continues to move toward leaner direct injection schemes. Effective suppression of the high-frequency combustion instabilities which result from the relatively short aero-engine combustor geometries is a critical enabling technology for lean-burning ultra-low-emission combustors and requires several key issues to be addressed. Dynamic models play a vital role in understanding the instability phenomenon and also for developing controls. Sensors and algorithms able to detect and interpret the instability need to be developed. Actuator devices that can introduce controlled-perturbations into the combustor to affect change in the instability are needed. And lastly, suitable control algorithms are needed to drive the actuators to obtain the necessary effect.

In recent years, there has been considerable activity addressing active combustion control. Government, academia, and industry research efforts, through analysis and the use of laboratory combustors, have shown the considerable potential for active control (Refs. 5 to 15). At the NASA Glenn Research Center, the Active Combustion Control Technology activity aims to demonstrate active control in a realistic environment relevant to aircraft engines by providing experiments tied to aircraft gas turbine combustors. The intent is to advance the technology maturity of active combustion control toward eventual demonstration in an engine environment. Previous work at NASA Glenn has shown that active combustion control utilizing advanced algorithms working through high frequency fuel actuation can effectively suppress combustion instabilities in a conventional, rich-front-end combustor. The combustor was developed in conjunction with Pratt \& Whitney and United Technologies Research Center and emulated a conventional aircraft gas turbine engine and its instability behavior (Refs. 16 to 19). For this effort, a suitable high-frequency fuel modulation device was developed by Georgia Institute of Technology and employed for modulating the combustor's main stage fuel injector. A high-temperature single crystal silicon carbide ( $\mathrm{SiC}$ ) pressure sensor was able to detect the existence of the thermoacoustic instability in the combustor test rig while operating at $780^{\circ} \mathrm{F}\left(420^{\circ} \mathrm{C}\right)($ Ref. 20$)$. Two combustion instability control algorithms were each able to demonstrate up to 90 percent suppression of the combustor instability (Refs. 17 and 18). A dynamic model was utilized to evaluate instability control methods, and also to gain insights into the instability phenomenon (Ref. 21). It is desired to extend these active control technologies to advanced ultra-low-emissions combustors such as those employing multipoint lean direct injection (Ref. 22).

In order to continue to mature the active combustion control technologies, a near term, but technically advanced low emissions combustor test bed is desired. Emissions testing of an advanced low-emissions combustor prototype was performed in 2006 in one of the combustion test cells at the NASA Glenn Research Center. During this testing, combustion instability pressure oscillations were observed. In addition, the instability pressure oscillations were observed to grow with increasing fuel/air ratio (FAR). This instability growth prevented the combustor from reaching full power operation. Dynamic data 
acquired from that combustor was analyzed in order to characterize the instability behavior of the combustor. Specifically, trends in instability amplitude versus operating conditions were observed and documented (Ref. 23). The dynamic characterization identified the combustor prototype as a suitable test bed for active controls research.

A combustion instability simulation, previously developed at NASA Glenn (Ref. 21), was modified to capture the specific geometry and operating conditions of the advanced combustor prototype. The simulation layout embodied the relevant physical features of the combustor and test rig in order to provide a simulation of the experimentally observed instability behavior. The simulated combustion instability closely matched that of the combustor for steady fuel flow and also replicated the growth in instability amplitude as the FAR increased (Ref. 23).

Most recently, in 2010, one of the previously developed instability control methods, the Adaptive Sliding Phasor Averaged Control (ASPAC) (Ref. 18) was updated for the low-emissions combustor prototype. Active combustion instability suppression using the ASPAC control method has been demonstrated experimentally with this combustor prototype in a NASA combustion test cell operating at engine pressures, temperatures, and flows. Dynamic pressure sensors in the combustor and in the combustor inlet provided combustor pressure feedback to the controller. A high-frequency fuel valve was utilized to perturb the combustor fuel flow. Successful instability suppression was shown. It was also demonstrated that the controller can prevent the instability from occurring while combustor operation was transitioning from a stable, low-power condition to a normally unstable high-power condition.

This paper provides a description of the combustor rig experimental setup and synopsizes the experimental dynamic characterization. The sensors and fuel actuator used for active control are then described. An overview of the instability control method and how it was adapted for the low-emissions combustor is then given. Data from the experimental demonstration of combustion instability control are provided and discussed. The paper concludes with a summary of the experimental results and a discussion of the continuing technical challenges and long range plans for NASA's efforts in active combustion control.

\section{Description of the Experimental Hardware and Software}

\section{Low-Emissions Combustor Prototype}

Several advanced low emissions combustor concepts for aircraft gas turbine engines have been developed in conjunction with NASA's industrial partners. Thermoacoustic instability was observed during emissions testing of one of these advanced combustor prototypes in 2006. This combustor prototype operates on liquid jet fuel (typically JetA or JP8) and consists of a pilot and main stage. The pilot operates locally rich and the main stage operates locally lean, however the overall fuel/air ratio (FAR) is always lean with typical equivalence ratio of $\phi=0.3$ to 0.5 (FAR $=0.02$ to 0.034 ). Here $\phi=1$ is the stochiometric FAR (for liquid jet fuel, $\phi=1$ is equivalent to FAR $=0.068$ ).

The combustor was installed in a flame tube in test cell CE5 at NASA Glenn (Fig. 1). The combustor and rig were operated at the range of conditions shown in Table I. The combustor was instrumented with dynamic pressure transducers at the locations shown in Figure 1. There were two water cooled dynamic (AC-coupled) pressure transducers upstream of the fuel injector $\left(P_{3 \text { DynA }}, P_{3 \text { DynB }}\right)$. Downstream of the fuel injector, two uncooled dynamic pressure transducers $\left(P_{4 \mathrm{DynUp}}, P_{4 \mathrm{Dynnn}}\right)$ were each installed in a purged, semi-infinite line configuration in order to isolate the transducers from the hot combustion products. The downstream transducer, $P_{4 \mathrm{DynDn}}$, had less background noise and is the one most often used for the dynamic characterization and feedback control presented in this paper. 


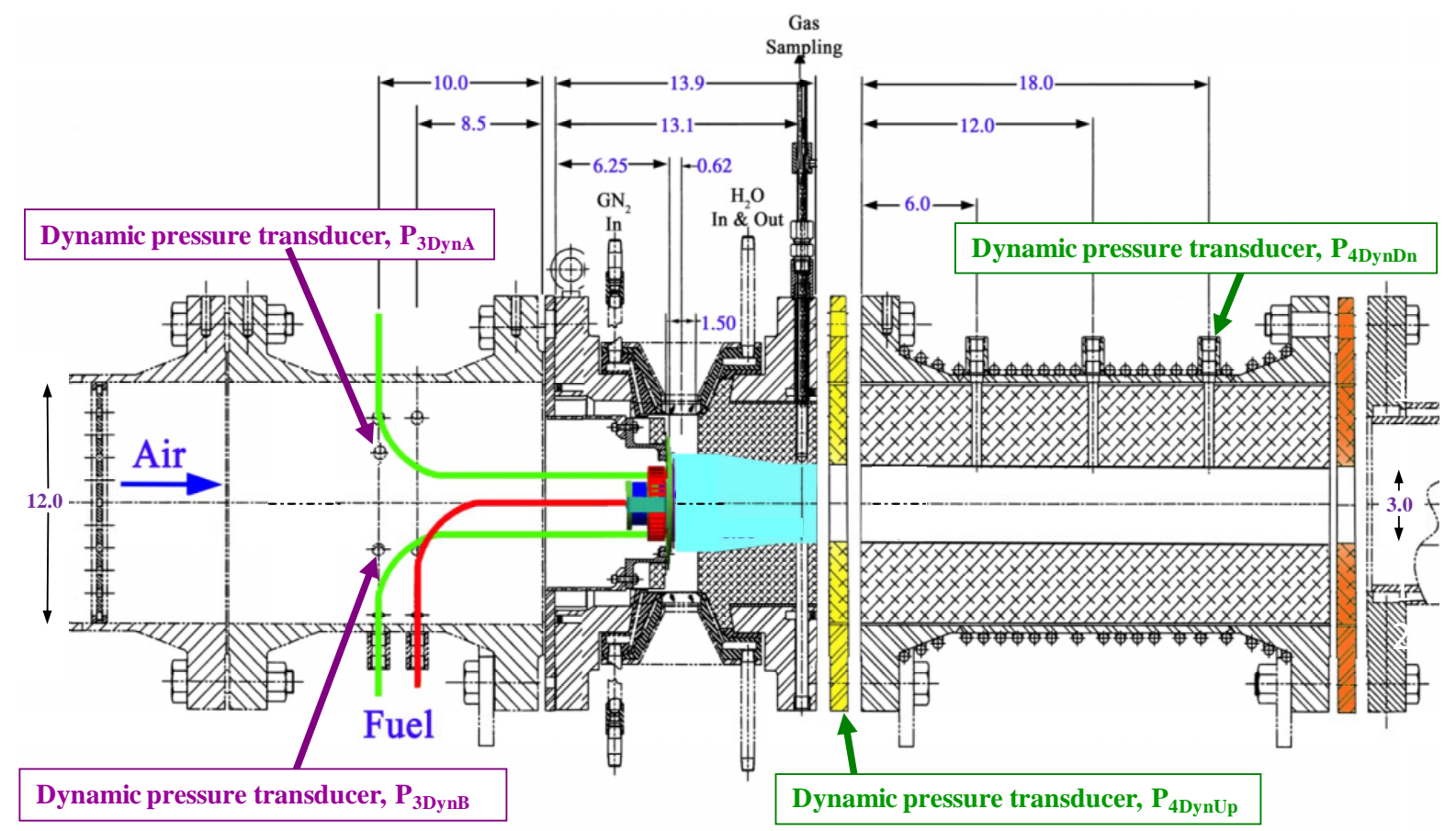

Figure 1.-Advanced low-emissions combustor prototype installed in NASA flame tube. The pilot fuel line is shown in red and the main stage fuel lines are shown in green. Dimensions shown are in inches. Drawing is not to scale.

TABLE I.-RANGE OF COMBUSTOR OPERATING CONDITIONS

\begin{tabular}{|l|l|}
\hline Inlet pressure (psia) & 65 to 250 \\
\hline Inlet temperature, ${ }^{\circ} \mathrm{F}$ & 400 to 1000 \\
\hline Air flow, $\mathrm{lbm} / \mathrm{s}$ & 0.9 to 4.0 \\
\hline Fuel flow, $\mathrm{lbm} / \mathrm{hr}$ & approx. 100 to approx. 400 \\
\hline Combustor $\Delta P / P$, percent & approx 4.0 to 4.5 \\
\hline Fuel/air ratio & 0.02 to 0.034 \\
\hline
\end{tabular}

\section{Characterization of Combustion Instability Versus Operating Conditions}

During emissions testing with this combustor in 2006, dynamic pressure data were collected and the dynamic behavior of the combustor characterized (Ref. 23). Observations from this test series showed an instability that occurred at approximately $530 \mathrm{~Hz}$. This instability was only present when operating on the main stage of the fuel injector, that is, it was not present for low power, pilot-only operation. Further, the instability was seen to generally increase in amplitude with increasing FAR. Due to concerns about damage to the fuel injector as the instability amplitude increased, the combustor was not operated at its full power FAR. The dynamic pressure data were recorded on a dSPACE Inc. real-time data acquisition system along with operating condition data. This allowed data to be acquired during instability, and also during the onset of instability. For all of the analyses shown in this paper, combustor dynamic pressure data were acquired with a sample time of $5 \mathrm{kHz}$. For steady fuel flow conditions, $10 \mathrm{sec}$ of data were typically acquired. The data were processed to obtain a power spectral density (PSD) of the pressure. The MATLAB (The Mathworks, Inc.) PSD function, which implements Welch's method, was applied to the data. A Fast Fourier Transform (FFT) length of 4096 was used and the data were segmented with a Hanning window of length 4096 and a window overlap of 75 percent of the window size. The spectral data were scaled to provide spectral amplitude in psi. A plot of the resulting peak value from the spectral data (the value at the instability frequency) versus FAR is shown in Figure 2. A simple curve-fit has been added for each set of data points to aid identification of trends in the data. Repeats during later test runs are included and are shown in Figure 2 as hollow symbols with dashed-line curve fits. The curves are 


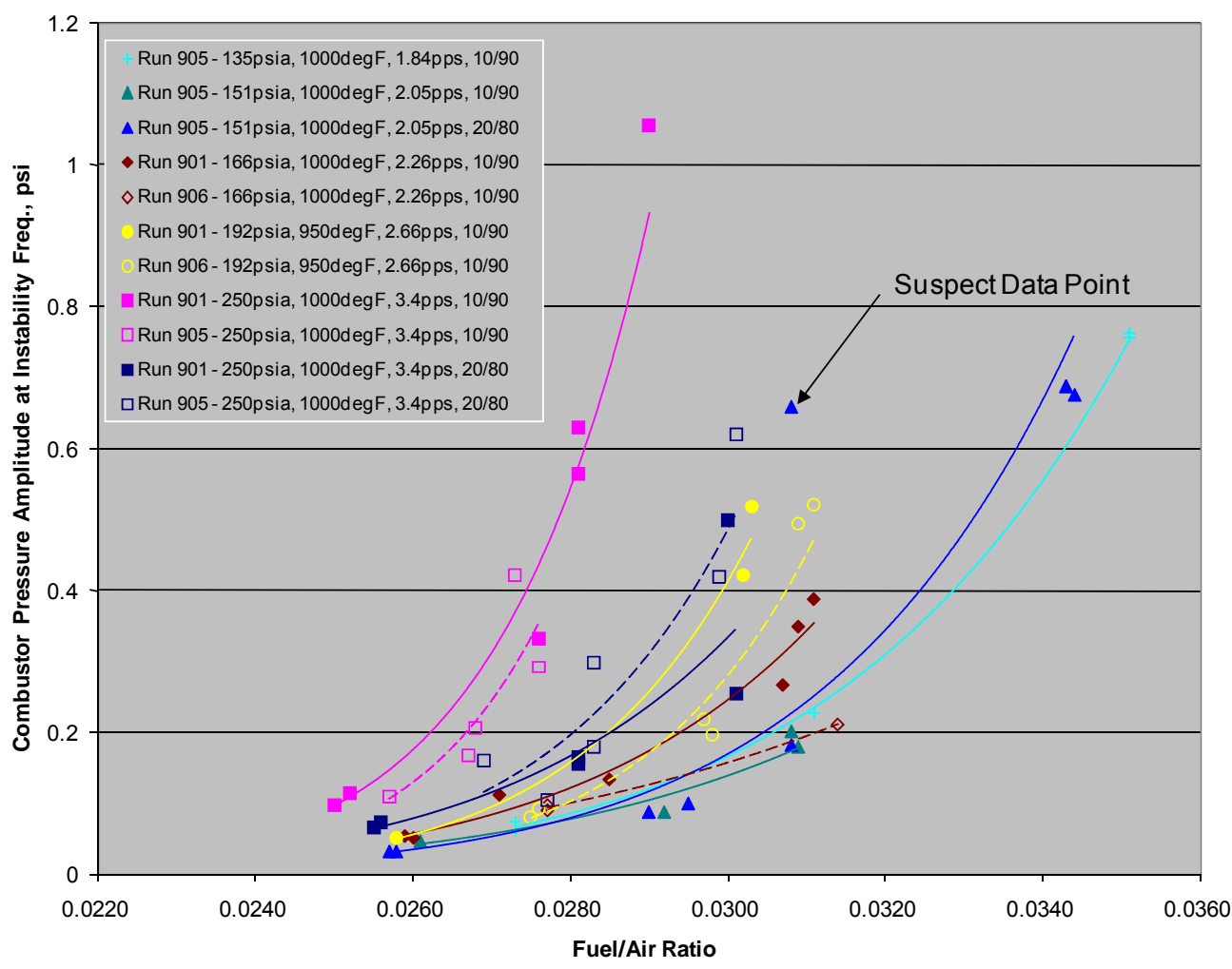

Figure 2.-Combustor pressure peak instability amplitude versus fuel/air ratio for multiple test runs shows increase in combustion instability amplitude with increasing fuel/air ratio (from Ref. 23).

labeled according to run number, combustor inlet pressure, combustor inlet temperature, combustor airflow, and pilot/main fuel split percentage. The overall trend of instability peak amplitude increasing with FAR can be seen in all the data sets. Further details on the dynamic characterization of the combustor can be found in Reference 23.

Due to the repeatable nature of the exhibited combustion instability across multiple operating conditions, as well as the ability to size the instability by varying FAR and operating conditions, this leanburn combustor prototype was selected as a suitable test bed for the combustion control effort described later in this paper.

\section{Instability Control Sensors}

As mentioned previously, and as shown in Figure 1, four high-frequency pressure sensors were used to measure thermoacoustic pressure oscillations in the combustor prototype during the 2006 combustor testing. For the instability control demonstration described in this paper, similar dynamic pressure sensors were used at similar locations. For the combustor inlet pressure $\left(P_{3}\right)$, two dynamic (AC-coupled) pressure sensors $\left(P_{3 \text { DynA }}, P_{3 \text { DynB }}\right)$ were located approximately $17 \mathrm{in.}(43 \mathrm{~cm})$ upstream of the fuel injector face at two different circumferential locations. These sensors are PCB Piezotronics type 123Mxx pressure sensors with \pm 100 psi range. Water cooling is used to keep the sensors below their maximum operating temperature of $250^{\circ} \mathrm{F}\left(120^{\circ} \mathrm{C}\right)$. For the pressure inside the combustor $\left(P_{4}\right)$, two dynamic pressure sensors $\left(P_{4 \mathrm{DynUp}}, P_{4 \mathrm{DynDn}}\right)$ were located at approximately $7 \mathrm{in} .(18 \mathrm{~cm})$ and $27 \mathrm{in} .(68.5 \mathrm{~cm})$ downstream of the fuel injector face, respectively. These sensors are PCB type 112Axx sensors with \pm 100 psi range. These sensors are each located approximately 12 in. $(30 \mathrm{~cm})$ from the flowpath on a purged, semi-infinite line. A comparison of how well the sensors at $P_{3}$ are able to measure combustion instability versus those at $P_{4}$ is given later in the experimental results section. 


\section{High-Frequency Fuel Actuator}

For the open-loop fuel modulation testing and closed-loop instability control testing, a high-frequency fuel modulation valve developed previously (Refs. 18 and 19) was utilized. The valve is actuated by a rod comprised of a magnetostrictive material. The fuel valve has an associated control system with a mean flow control loop that keeps the mean fuel flow constant while the fuel flow is perturbed. The design application for the valve was to modulate the main stage fuel at up to $1000 \mathrm{~Hz}$. For the previous combustion control application (Refs. 16 to 18), the combustor main fuel injector Flow Number was about 110. Flow Number for an orifice is defined as:

$$
\text { Flow Number }=\frac{\dot{m}}{\sqrt{\Delta P}}
$$

with $\dot{m}$ being the fluid mass flow rate in $\mathrm{lbm} / \mathrm{hr}$ (abbreviated pph) and $\Delta P$ being the pressure differential in psi across the orifice. The resulting units for Flow Number are ( $\left.\mathrm{pph} / \mathrm{psi}^{0.5}\right)$, though they are rarely stated. ${ }^{1}$

It was desired for the current test that the valve modulate the fuel flow through the fuel injector pilot which carries a smaller portion of the overall fuel flow (typically 10 to 20 percent) through a correspondingly smaller Flow Number of approximately 8. Using a dynamic flow test rig (Ref. 24), the fuel valve was dynamically characterized to try to predict how well it would be able to modulate the pilot fuel. Fuel line lengths and sizes were set in the characterization rig to approximate the lengths and volumes for the fuel feed system in the combustor rig. The results of the valve dynamic characterization (Ref. 25) suggested that the fuel valve, operating through the pilot, might not have enough actuator authority to impact the combustion instability. However, since no appropriately sized valve was available at the time, it was decided to proceed to combustion testing. As a fallback position, the valve would be used to modulate the main stage fuel, which for this fuel injector had a Flow Number of approximately 30. The performance of the valve during combustor testing is described in the experimental results section of this paper.

\section{Control Method Description}

The Adaptive Sliding Phasor Averaged Control (ASPAC) algorithm was developed previously and used to control combustion instability in a conventional, rich-burn combustor. The control algorithm and previous results are described in detail in Reference 18. As depicted in Figure 3, combustor thermoacoustic instability is a closed-loop, self-excited process that occurs when combustion excites the combustor acoustics, and the acoustics feed back into the combustion process with the appropriate phase. To suppress combustion instability, a controller must interrupt this naturally occurring feedback. The ASPAC algorithm senses combustor pressure fluctuations, uses a band-pass filter to isolate the instability frequency, and modulates the fuel valve. The pressure oscillations generated by combustion of the ASPAC-modulated fuel oppose in phase the pressure oscillations generated by the instability, reducing the net amplitude of the combustor pressure oscillations. As shown diagrammatically in Figure 4, the sensed pressure is phase shifted with a phase that slides back and forth inside a restricted control region that the controller has identified as being favorable to suppression of combustion instability. This phase shifted pressure is used to generate the command to the fuel valve. The combustor pressure resulting from heat addition due to the fuel modulation, vectorially adds to the combustor pressure due to the instability to provide the overall dynamic combustor pressure. The dashed line region (the "effective stability region") within the shaded area in Figure 4 is the stable region in which the phase of the fuel modulation

\footnotetext{
${ }^{1}$ The effective flow area of a pressure atomizer such as a fuel injector nozzle is often described in terms of Flow Number. However, Flow Number is dependent on the fluid density (Ref. 1). For reference, with jet fuel, a Flow Number of 110 correlates to an effective cross-sectional area of approximately $6.5 \times 10^{-3}$ in.
} 


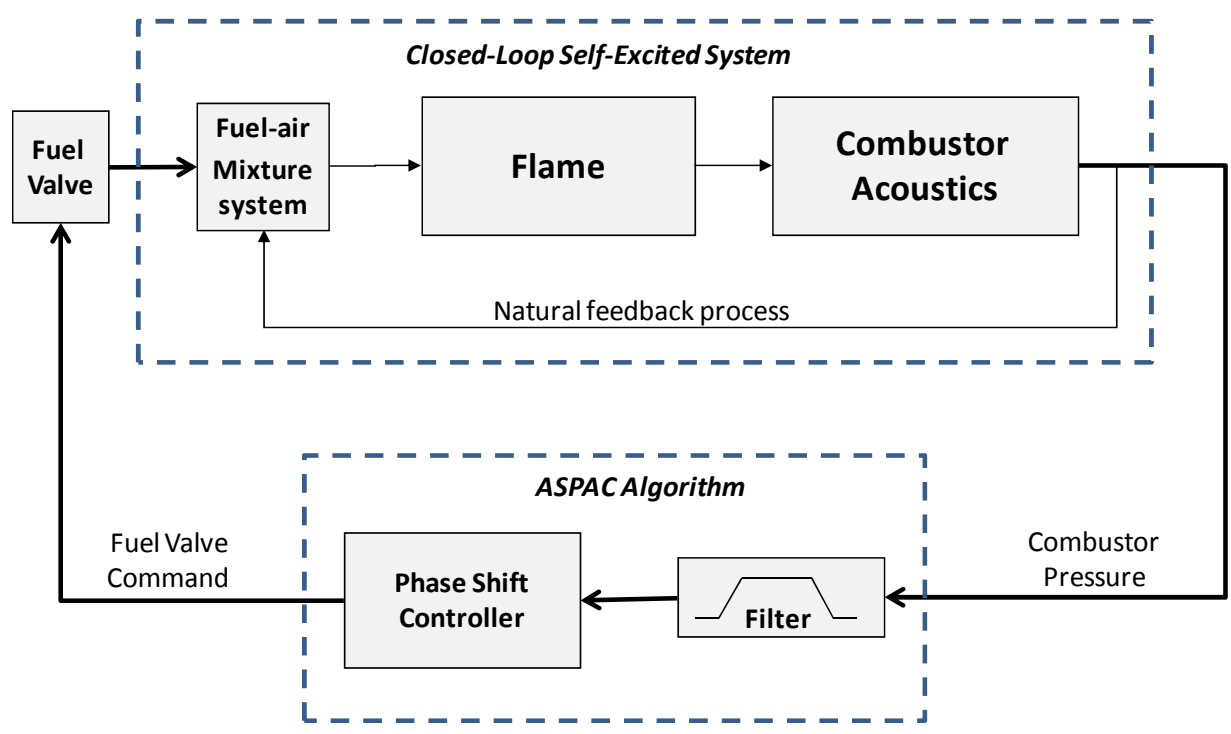

Figure 3.-ASPAC combustion instability control block diagram showing filter and phase shift controller that are the heart of the ASPAC algorithm.

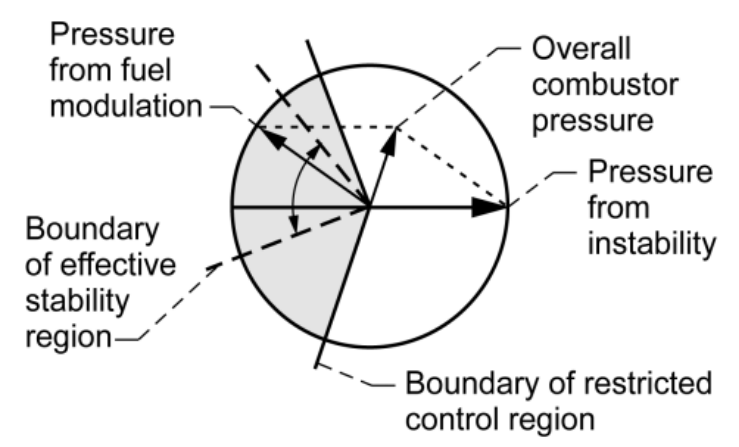

Figure 4.-ASPAC Phasor diagram depicted in a stationary frame of reference shows how pressure from properly phased fuel modulation decreases overall combustor pressure oscillations.

relative to the instability pressure is such that the power of the combustor pressure oscillations is reduced. The controller phase slides back and forth within the effective control region; starting from one end of its boundary, marching to the other end and then reversing direction. This continuous dithering of the phase allows the controller to respond quickly to any changes in phase required to maintain instability suppression.

The controller command is generated at a $10 \mathrm{KHz}$ rate and the controller calculates and applies a new phase shift at a rate of $40 \mathrm{~Hz}$. Also, this controller optionally employs discontinuous exponential gain modulation control. In this control mode the gain toggles on and off with an exponential decay in order to counteract the effective proportional gain variability produced by the large dead time phase delay of the plant. In addition, controller parameter adaptation is employed to tune some of the key parameters of the controller.

For the current effort, the ASPAC controller has been updated to provide active control of combustion instability in the low-emissions combustor prototype. The controller was modified via the band-pass filter design, to be more sensitive to the instability frequencies observed in the low-emissions combustor. Initially, a simple non-linear oscillator model was used to tune and exercise the controller. In order to conduct more detailed simulation evaluations of instability control methods, and also to gain insights into the instability phenomenon, the NASA Sectored 1-D combustion instability simulation method was 
utilized. The simulation layout embodies the relevant physical features of the combustor and test rig. As described in Reference 23, modifications were applied to the basic simulation in order to match the physical layout shown in Figure 1, and capture the experimentally observed instability behavior of the low emissions combustor prototype as shown in Figure 2. The Sectored 1-D simulation was used in a limited fashion for evaluation of the controller prior to experimental testing of the controller in the combustor rig. Further runs with the Sectored 1-D simulation are planned with the results to be compared to the experimental data described next. However, as will be discussed, the behavior of the combustor rig changed with time so that the Sectored 1-D simulation, which captured the relatively static behavior of the rig in the 2006 testing, no longer captured this changing combustor instability behavior. The discussion of experimental results later in this paper briefly explores options on how to proceed with postrun simulation evaluations.

\section{Instability Control Experimental Demonstration}

The updated ASPAC controller was implemented on a dSPACE Inc. real-time control computer and operated with the low emissions combustor prototype to experimentally demonstrate combustion instability control. Experimental testing was conducted in the NASA Glenn Research Center combustor test cell CE5 from September through November of 2010. There were five research objectives for the experimental program:

A. Determine if the combustion instability behavior of the low-emissions combustor prototype is similar to that observed during the 2006 testing;

B. If Objective A yields a suitable operating condition for combustion instability control investigations, attempt to demonstrate that the ASPAC controller is able to suppress combustion instabilities in the low-emissions combustor prototype and, as a result, extend the combustor operating range into previously unstable regions;

C. If Objective B is successful, determine if combustion instability control can be accomplished using the dynamic pressure at $P_{3}$ for feedback;

D. Also, if Objective B is successful, determine if combustion instability control can be accomplished through modulation of the pilot fuel flow; and

E. Obtain dynamic characterization data during the closed-loop, instability control activities in Objectives B through D to allow construction of a closed-loop version of the Sectored 1-D combustor simulation that can be used as a benchmark problem for evaluating other combustor instability control methods and/or other combustion instability simulation methods.

Experimental results addressing each of these research objectives are presented and discussed in the following sections.

\section{Comparison of Combustion Instability Behavior Versus Prior Testing}

As discussed previously, the combustion instability behavior of the low-emissions combustor prototype as shown in Figure 1 was dynamically characterized to obtain the relationship between combustion instability and operating conditions such as air temperature, air pressure, and fuel/air ratio. The results from testing in 2006 are reported in Reference 23 and are summarized in Figure 2. Since several years and several rig configuration change-outs had occurred, the first set of test runs in 2010 attempted to replicate the 2006 behavior. The expectation was that the combustor would behave similarly. Sensor $P_{4 \mathrm{DynDn}}$ was again used to measure instability pressure oscillations. As was seen in 2006 , the instability was only present when operating on the main stage of the fuel injector, that is, it was not present for low power, pilot-only operation. Comparisons were then run for combined pilot/main 


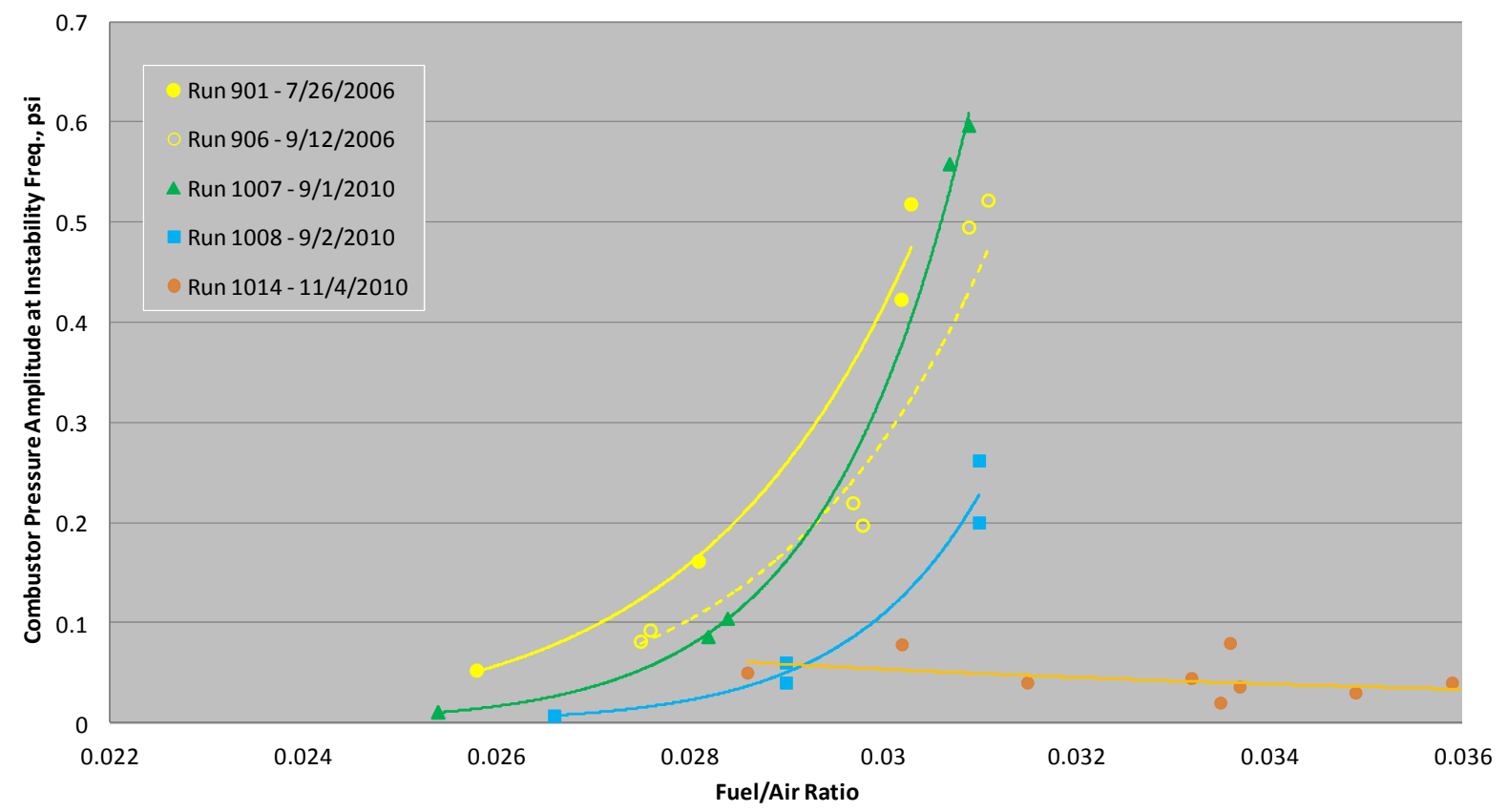

Figure 5.-Combustion instability pressure peak amplitude versus FAR for a single representative operating condition shows decreasing instability amplitude versus time in 2010 as compared to 2006 instability behavior. The data shown is for $P_{3}=192 \mathrm{psia}, T_{3}=950{ }^{\circ} \mathrm{F}, \dot{m}_{\text {air }}=2.66 \mathrm{lbm} / \mathrm{s}, 10 / 90$ fuel split (Pilot/Main).

operation. Figure 5 shows, for one of the operating conditions shown in Figure 2, the 2006 instability behavior versus FAR compared to the same operating condition during the 2010 runs. As can be seen in the figure, during the first 2010 run, the instability behavior (amplitude vs FAR) seemed similar to that observed in 2006. However, as also seen in Figure 5, after the first run, the instability amplitude decreased from run to run. Eventually the combustor was essentially quiet and there was no increase in instability amplitude with increasing FAR. Similar behavior (that is, a decrease in susceptibility to instability) was observed for all other operating conditions as well. It was found that to obtain instability pressure oscillations of sufficient amplitude to conduct the combustion instability control experiments described next, it was necessary to operate the combustor off-design. For example, decreasing the combustor $\triangle P / P$ for the same FAR was found to increase the instability amplitude. The resulting actual conditions used for combustion control testing will be described in the next section.

A definitive cause for the continual decrease in susceptibility to instability was not identified during the testing. It was suspected that the fuel injector might be accumulating some damage that was changing how the fuel and air were delivered to the combustor. However, examination of the fuel injector hardware between runs showed no obvious physical changes. Near the end of the test cell entry, it was noticed in the test data that the main stage fuel injector Flow Number had been decreasing steadily over the weeks of testing (Fig. 6). It was suspected that this may have been due to coking. Between two of the runs, detergent was run through the fuel injector and the Flow Number partially (but only temporarily) recovered, as did the instability amplitudes. It was hypothesized, but not verified, that the change in fuel injector Flow Number may have changed how the fuel was delivered to the flame, thus impacting the instability mechanism. Since the attempted fix was only partial, and temporary, it remained necessary to run the fuel injector off-design to get sufficient instability amplitudes for controls testing. 


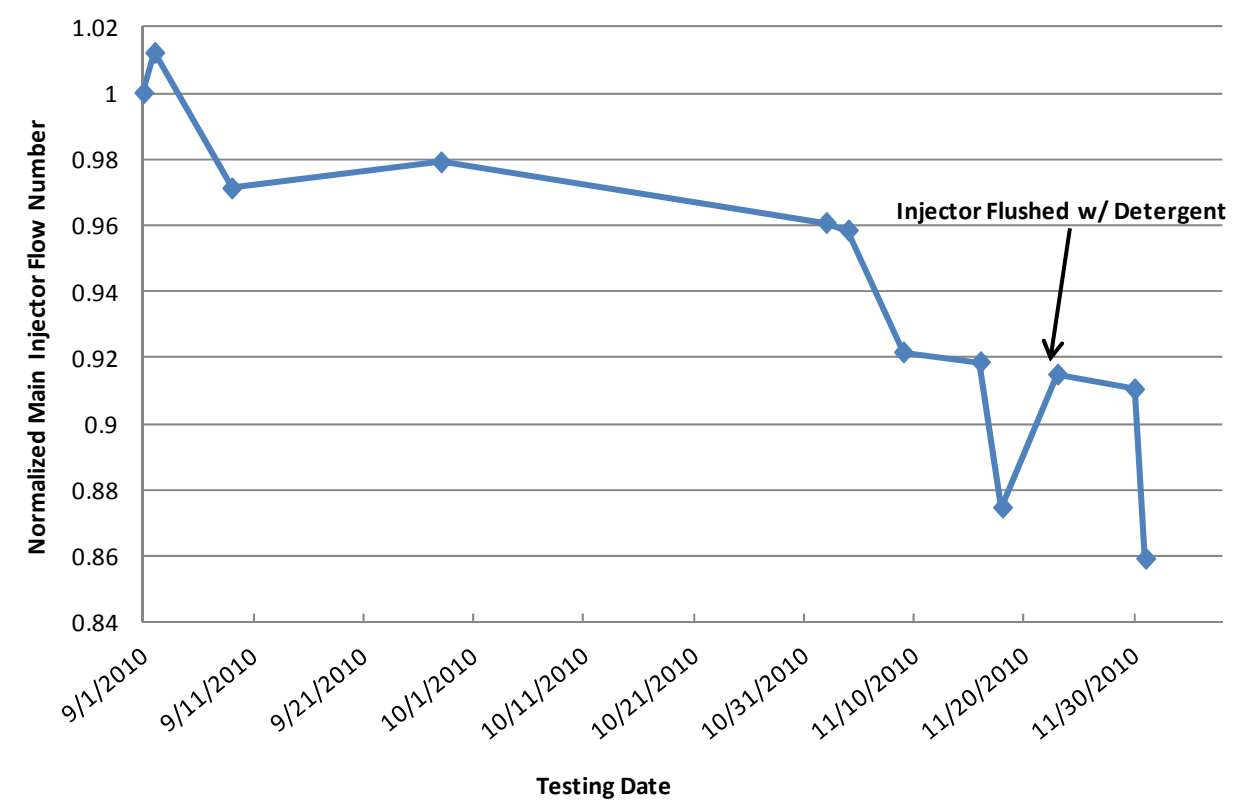

Figure 6.-Main fuel injector average flow number from each test date, normalized to initial flow number, shows flow number decreasing over time. Flow number partially recovered when the fuel injector was flushed with detergent to remove possible coking.

\section{Demonstration of Combustion Instability Control}

From the testing described in the previous section, the operating condition $P_{3}=166 \mathrm{psia}, T_{3}=$ $1000^{\circ} \mathrm{F}$, with pilot/main fuel split percentage of 10/90 was chosen for instability control investigations. Depending on the FAR and combustor $\triangle P / P$ chosen, this point exhibited an instability with peak pressure amplitude of between 0.5 and 1.0 psi peak amplitude (1 to 2 psi peak-to-peak) at approximately $620 \mathrm{~Hz}$. Figure 7 shows the amplitude spectra and time history plot of the combustor dynamic pressure, $P_{4 \mathrm{DynDn}}$, for a FAR of 0.037 and combustor $\triangle P / P$ of 3 percent. The pressure oscillations can clearly be seen in the amplitude spectra as well as in the time history. There is also a small harmonic response. The $620 \mathrm{~Hz}$ instability frequency observed here is higher than the $530 \mathrm{~Hz}$ instability observed in the 2006 testing. This is believed to be due to the higher FAR required to elicit the instability producing a higher temperature and thus a higher speed of sound in the combustor.

The high-frequency fuel modulation valve was installed in the main stage fuel injector supply line as close to the fuel injector as the rig installation would allow (about where the word "Fuel" is shown on Fig. 1). This was about 3 in. from the rig pressure vessel. However, due to stress relief bends in the fuel line inside the pressure vessel, there was still approximately $32 \mathrm{in.} \mathrm{from} \mathrm{the} \mathrm{fuel} \mathrm{valve} \mathrm{to} \mathrm{the} \mathrm{fuel} \mathrm{injector}$ tip. Open-loop, sinusoidal valve command variations were provided to the valve to observe the response of combustor pressure to main stage fuel injector perturbations. The commanded frequency and voltage level to the valve were varied and combustor pressure $P_{4 \mathrm{DynDn}}$ monitored. The limits on valve command voltage were set to values found in prior testing (Ref. 25) to provide maximum linear valve travel without valve overheating. Fixed frequency and sweep frequency perturbations from 100 to $1500 \mathrm{~Hz}$ were commanded to the valve. Representative results are shown in Figure 8. Shown are the valve commanded voltage and the combustor dynamic pressure for commanded frequencies of 500 and $800 \mathrm{~Hz}$. Along with the instability pressure oscillations (as shown previously in Fig. 7), the response to the fuel modulations (and a small harmonic response) can also be seen in the combustor pressure. 

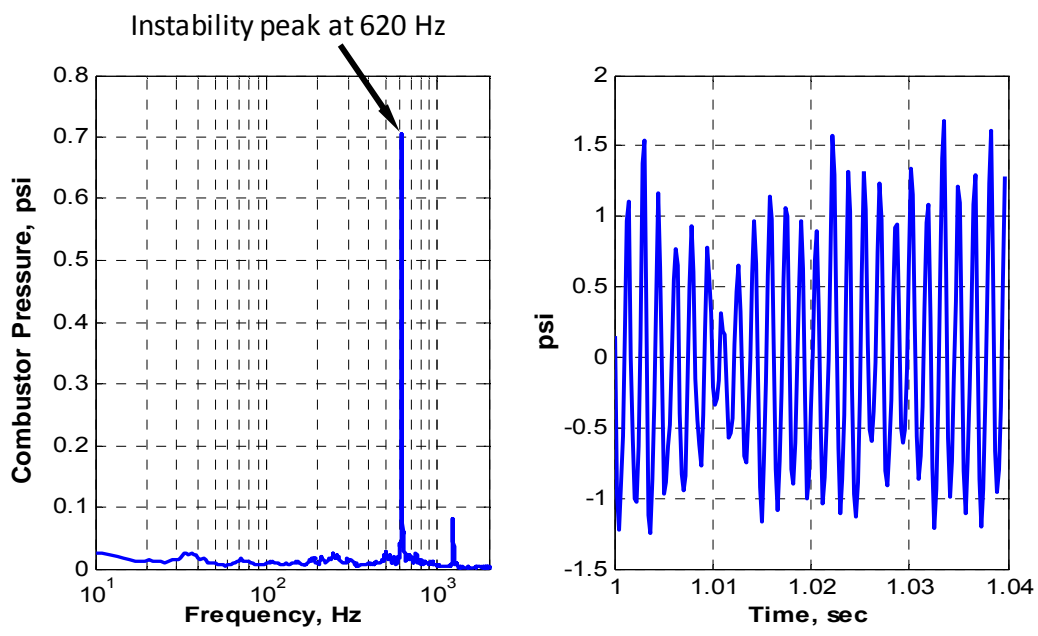

Figure 7.-Amplitude spectra and time history plot of combustor dynamic pressure showing the combustion instability at $620 \mathrm{~Hz}$ for operating conditions $P_{3}=166$ psia, $T_{3}=1000{ }^{\circ} \mathrm{F}, \mathrm{FAR}=0.037$ and combustor $\triangle P / P=3$ percent.
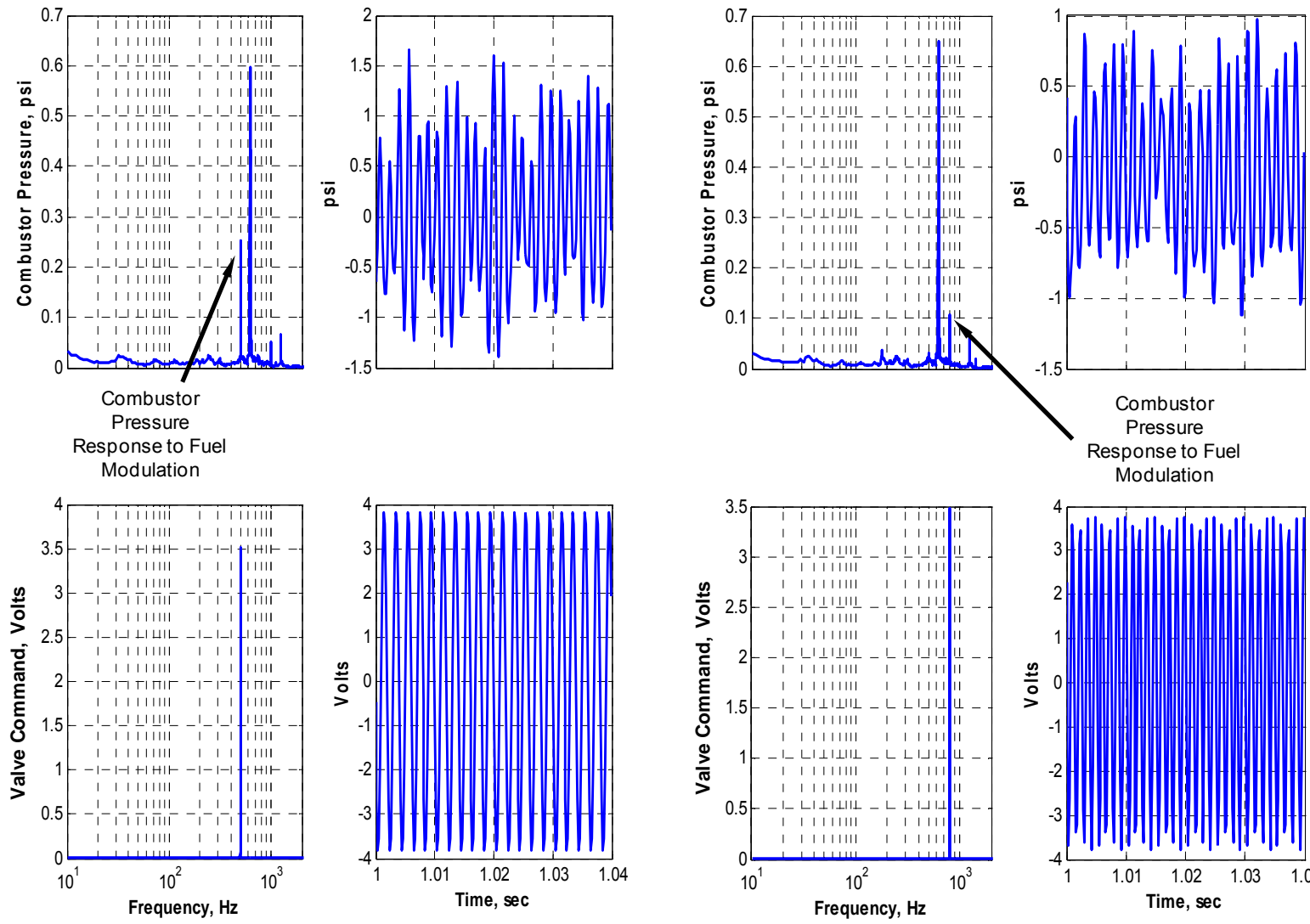

a) $500 \mathrm{~Hz}$
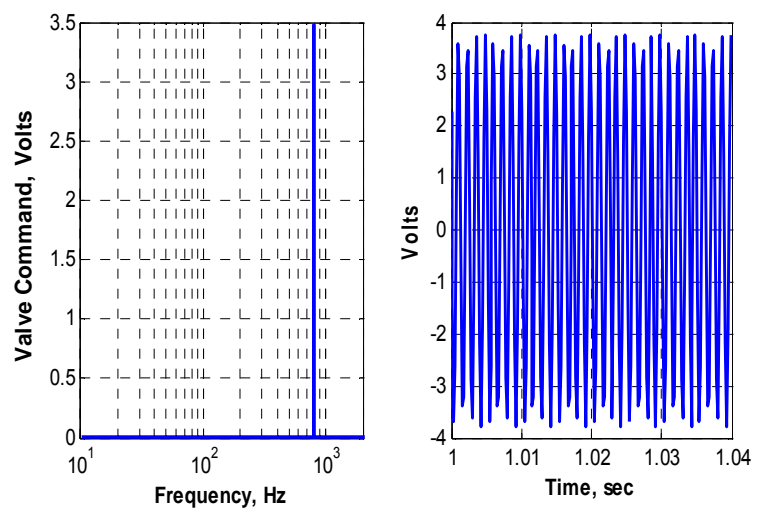

b) $800 \mathrm{~Hz}$

Figure 8.-Combustor dynamic pressure $\left(P_{4 \mathrm{DynDn}}\right)$ shows both the combustion instability and the response to open loop fuel perturbations commanded to the valve at two different frequencies. 
While the amplitude of the response to fuel modulation appears small relative to the amplitude of the instability, it was observed during testing that at certain frequencies, especially those close to the instability frequency (e.g., within $25 \mathrm{~Hz}$ ), the instability amplitude would get smaller. Also, for frequencies very close to the instability (e.g., within $10 \mathrm{~Hz}$ ), the instability frequency would shift to that of the fuel modulation frequency. Both of these effects indicate that the fuel modulation is affecting the instability and will thus be able to impact the instability via closed-loop control. It was thus concluded that fuel modulation via the main stage injector had sufficient authority to proceed to closed-loop testing.

With the instability behavior just described present in the combustor, the ASPAC controller was turned on, allowing it to command the fuel valve. The sensor $P_{4 \mathrm{DynDn}}$ was used as the controller feedback. Initially, the gain for the controller was manually set to zero, which commanded zero voltage perturbations to the valve. The gain was then slowly increased until good instability suppression was observed and then until the commanded voltage to the valve approached its limits. This was done to give the controller the maximum available actuator authority. However, it was found that increasing the gain beyond a certain value caused the instability suppression to be erratic. This is expected as a result of the large time delays and noise in the system. As the instability gets sufficiently small compared to the system noise, the noise will randomize the phase of the pressure oscillations. A large gain will then tend to excite the instability during those times when the ASPAC algorithm is going through larger-than-usual phase adaptations (i.e., when the phase is not completely correct for suppression).

Some manual and automated tuning of the controller's parameters (e.g., gain, filter pass-band, phase adaptation limits, instability growth allowed before large scale phase adaption kicks in, etc.) was then done to obtain the best instability suppression as determined from real-time spectral analysis of the combustor pressure. Figure 9 shows a combustion instability control result using $P_{4 \mathrm{DynDn}}$ as feedback and modulating fuel through the main stage injector. As shown in the spectral plots on the left, when the controller is on, the
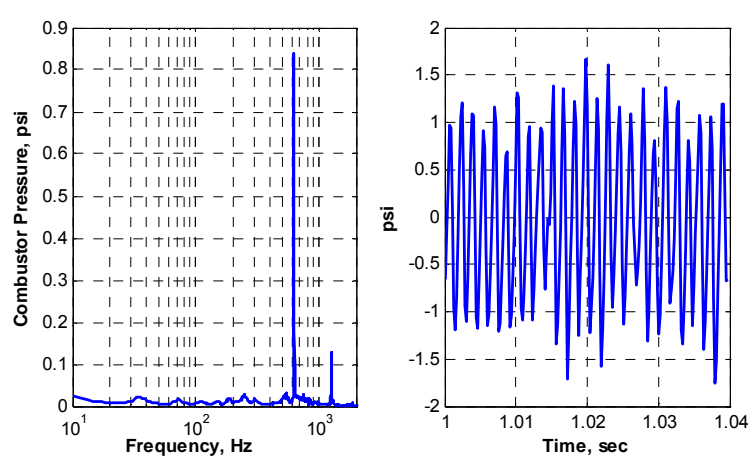

a) Without control
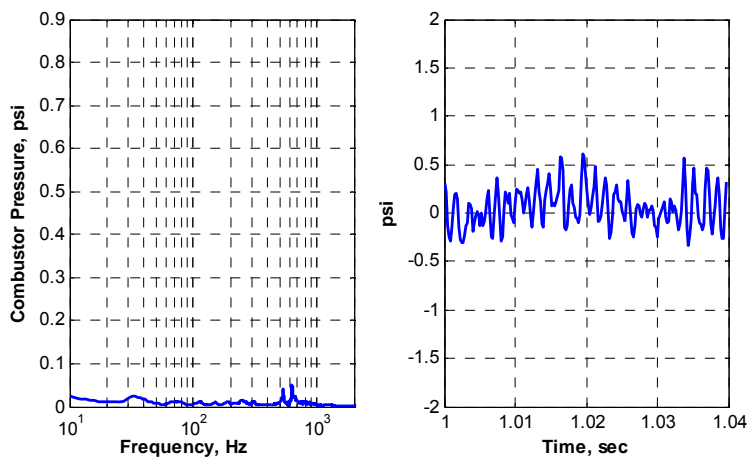

b) With control

Figure 9.-Combustor pressure amplitude spectrum (left) and time history (right) shows the combustion thermoacoustic instability being suppressed by the application of closed-loop control. For this data, $P_{4 \mathrm{DynDn}}$ was used as controller feedback, and the fuel valve was modulating fuel through the main stage fuel injector. 
amplitude of the pressure oscillations at the instability frequency is reduced by nearly 95 percent from its uncontrolled value (from 0.84 to $0.05 \mathrm{psi}$ ). The time history plot on the right shows a decrease in the peakto-peak pressure oscillations from about 2.5 psi to about 1 psi. A second oscillatory mode around $500 \mathrm{~Hz}$ was sometimes observed in the combustor pressure. This resonance can be seen in the left plots in Figure 9. Since the controller was not designed to address this other resonance, this sometimes limited the amount the time history of the pressure oscillations (as shown in the right side of Fig. 9) could be reduced.

A useful result would be to quantify how much fuel mass flow modulation is required to accomplish this instability suppression. However, there are no dynamic mass flow measuring devices in the fuel lines for this combustor rig, so the flow modulation must be estimated from the fuel injector $\Delta P$. Further, since no dynamic $\Delta P$ measurement across the fuel injector is available, the fuel injector $\Delta P$ is also estimated from the modulation valve exit pressure minus the time average $P_{4}$. The result is a very rough estimate of the size of the fuel modulations entering the combustor. The following example is for the case shown in Figure 9. First, Equation (1) is used to calculate the main injector Flow Number. Using the time-average value for valve exit pressure of $210 \mathrm{psia}$, for $P_{4}$ of $150 \mathrm{psia}$, and for fuel flow of $220 \mathrm{lbm} / \mathrm{hr}$, the main injector Flow Number is found to be 28. This is consistent with the expected value stated earlier in the paper. Next, the fuel mass flow modulation is estimated from the fuel injector $\Delta P$ and Flow Number by inverting Equation (1). From valve exit pressure modulations of approximately \pm 20 psi about the mean, the fuel mass flow modulations required for instability suppression are estimated to be around $\pm 35 \mathrm{lbm} / \mathrm{hr}$ or approximately \pm 8 percent of the mean fuel flow.

While it is interesting to know if the controller is able to suppress an instability that is already occurring, the more desirable controller action would be to prevent the instability before it has a chance to get large enough to be of concern. To test the ability of the ASPAC controller to prevent a combustion instability from developing, a fuel/air ratio transient was commanded by the facility operators to transition the combustor from a region of stable operation to a region of unstable operation (the facility controls the overall fuel and air through the combustor). This FAR transient, without the ASPAC controller active, is shown in the left part of Figure 10. Shown are the fuel modulation valve command (inactive in this case), the combustor dynamic pressure, and the FAR. The combustor pressure has been band-pass filtered about the instability frequency (the filter pass-band is about $100 \mathrm{~Hz}$ around a center frequency of $620 \mathrm{~Hz}$ ) in order to deemphasize noise and accentuate the pressure oscillations due to the instability.

As can be seen, with no control, the instability develops and the pressure oscillations due to the instability grow to approximately the levels shown in Figure 9. However, as shown in the right side of Figure 10, with the ASPAC controller active, repeating the same FAR transient shows no increase in pressure oscillations. Interestingly, the valve command shows very little increase in activity when the instability would be developing due to the fact that the controller is already monitoring combustor pressure and modulating the fuel valve to minimize the energy in the combustor pressure. These two FAR transients (with and without the controller active) show that the ASPAC controller is able to prevent the growth of instability before it can reach an unacceptable level. As discussed earlier, since the instability amplitude for the combustor grows with increasing FAR, in order to achieve higher power operation, the instability growth must be reduced or eliminated. The results shown here, then, are highly encouraging. They show that, with combustion instability control, the combustor can operate in regions that had previously been avoided due to instability, thus enabling an expanded operating range for the combustor.

Another experiment was conducted to observe how quickly the ASPAC controller is able to suppress an instability when the controller is switched on. This is of interest because, in contrast to the previous test, it would be operationally desirable to only have the controller active when an instability is starting to develop. This would decrease the activity of the high-frequency valve and extend its life. The left side of Figure 11 shows the ASPAC controller being turned on in the presence of an already developed instability. This would be the worst case, since, as was already discussed, it would normally be undesirable to let the instability become fully developed. As seen in the figure, after the controller is switched on at a little after $4 \mathrm{sec}$, the controller starts modulating the fuel valve command (the top plot) and is able to start impacting the instability pressure oscillations (the bottom plot) almost immediately. 

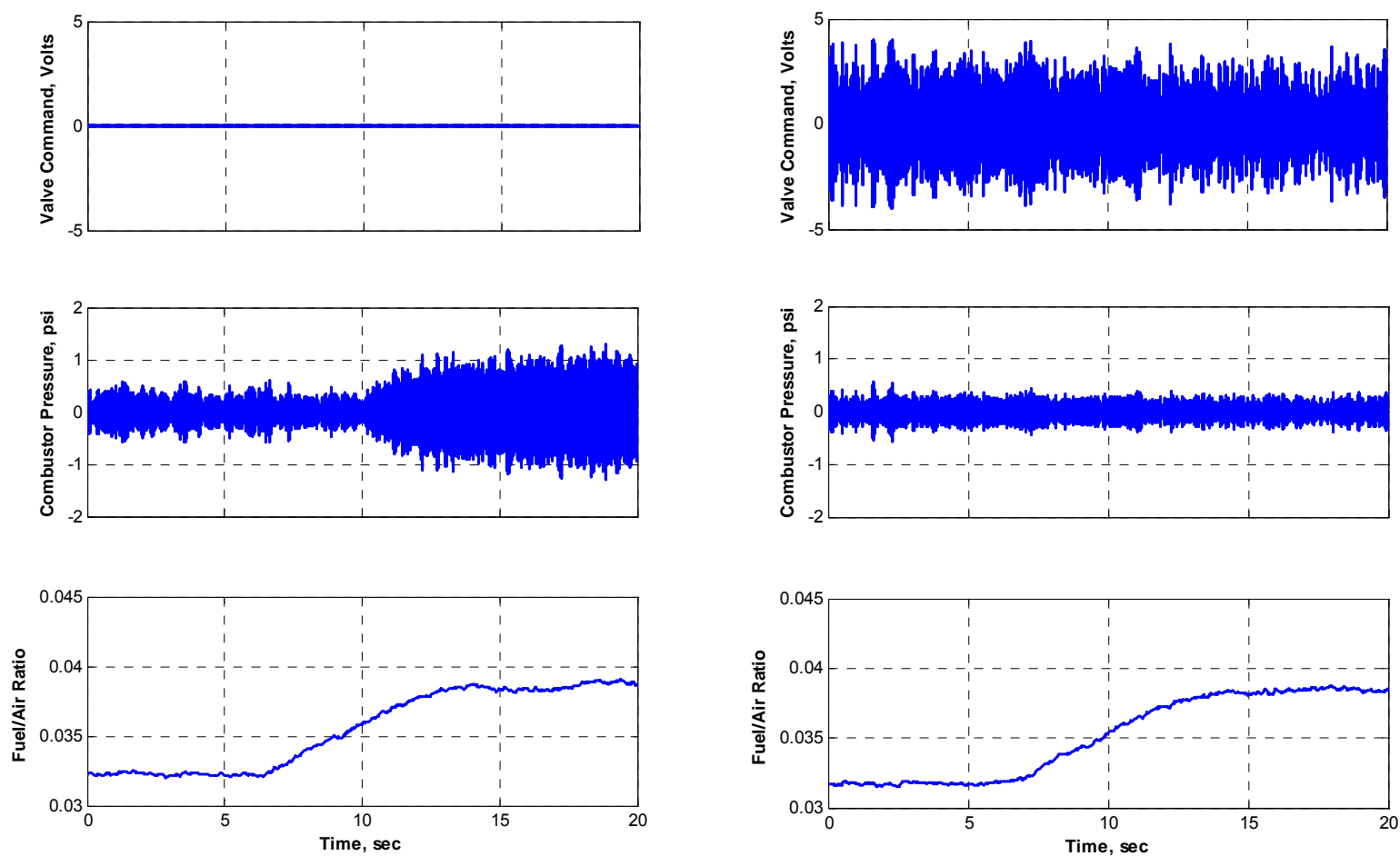

a) Without ASPAC control

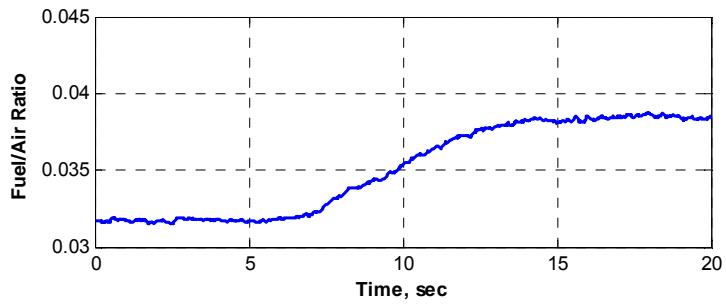

b) With ASPAC control active

Figure 10.-Growth of the combustion thermoacoustic instability is prevented by the application of the ASPAC closed-loop control during an increase in fuel/air ratio. Shown (bottom to top) are combustor rig experimental data for the fuel/air ratio, combustor pressure, and modulation valve command voltage.
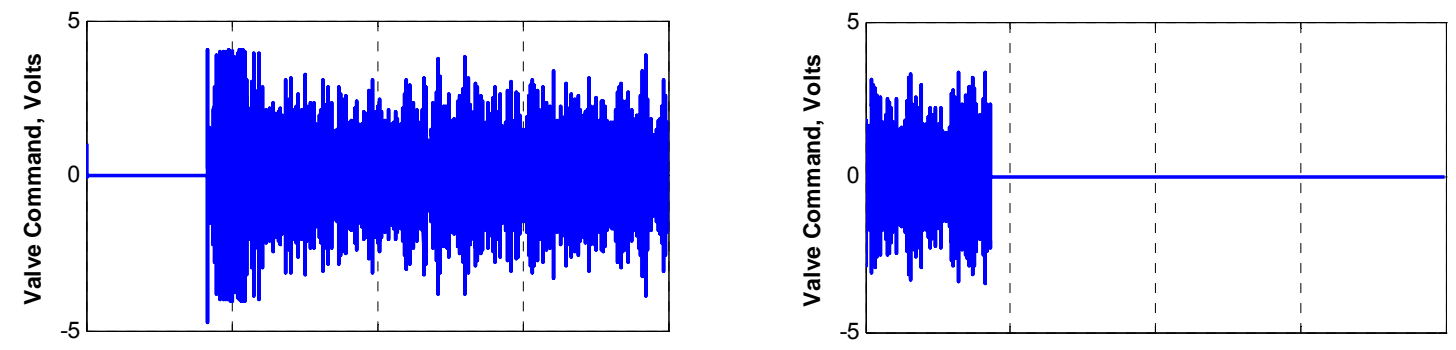

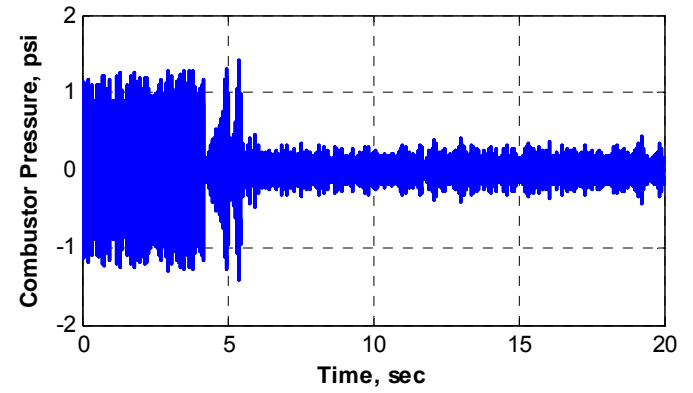

a) ASPAC controller switched on at $\sim 4 \mathrm{sec}$

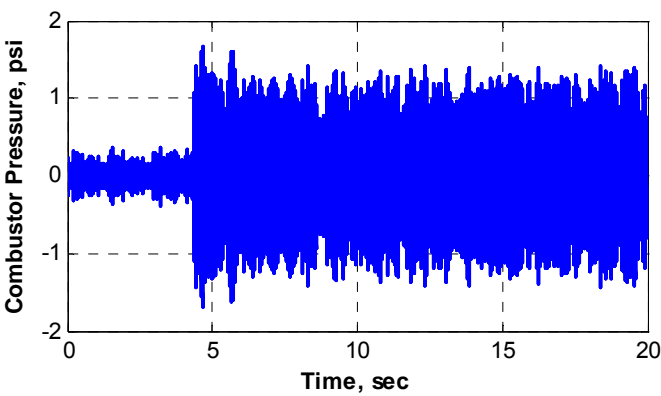

b) ASPAC controller turned off at $\sim 4 \mathrm{sec}$

Figure 11.-Time history of the fuel modulation valve command and the combustor pressure shows the time required for the ASPAC controller to suppress an already developed instability; and time required for an instability to re-develop when the ASPAC controller is switched from on to off. 
However, this early suppression is of poor quality in that it allows the instability to re-grow while the controller narrows the region of phase shifting required for suppression. The abilities of the controller early on are also limited due to the fuel valve saturating and not providing as much authority as the controller is requesting. As the controller converges on the optimum phase shift region, the quality of the suppression improves until the suppression is able to be maintained. The right side of Figure 11 shows that if the controller is turned off again, the instability quickly re-develops. These results show that the relative time for the instability to fully develop is shorter than the time the controller takes (from an entirely off state) to suppress this fully developed instability. This reinforces the importance of the previous results whereby the instability is prevented from developing. This also points to a desired mode of operation where the controller monitors the combustor pressure continually (or at least in the vicinity of conditions known to be prone to instability). The controller could then "get a head start" on instability suppression by observing the instability as it is starting to develop. This mode of controller activation was not able to be tested during this test cell entry, but is considered to be a highly desirable feature for future implementations of the ASPAC controller.

\section{Combustion Instability Control With $\boldsymbol{P}_{3}$ Dynamic Pressure as Feedback}

The typical temperature just upstream of the combustor $\left(T_{3} \leq 1300^{\circ} \mathrm{F}\right)$ is considerably less harsh than the typical temperature inside the combustor $\left(T_{4}>3000^{\circ} \mathrm{F}\right)$. Thus it is highly desirable to be able to utilize a pressure sensor at $P_{3}$ for controller feedback rather than one at $P_{4}$. Since pressure sensor technology is moving in the direction of pressure sensors that can operate at temperatures in excess of $1000^{\circ} \mathrm{F}$, being able to use $P_{3}$ for feedback instead of $P_{4}$ would enhance the technical viability of combustion instability control. To investigate the use of $P_{3}$ dynamic pressure for controller feedback, the measured dynamic pressure at $P_{3}\left(P_{3 \mathrm{DynA}}\right)$ was compared to the dynamic pressure at $P_{4}\left(P_{4 \mathrm{DynDn}}\right)$ (see Fig. 1 for the locations of these sensors). Figure 12 shows a comparison of the measured values for these two pressure sensors for the combustion instability condition shown previously in Figure 7. As can be seen, the pressure oscillations upstream of the combustor at $P_{3}$ are about one-third the size of those inside the combustion at $P_{4}$. However, the same spectral information about the instability is present. A similar relationship between $P_{3}$ and $P_{4}$ was seen at multiple operating conditions. An additional item of interest seen in Figure 12 is that the relative phase of sensed $P_{3}$ and $P_{4}$ (recorded at the exact same time) are not the same. This phase difference points to the assumed mode shape of the combustion instability of roughly a half-wave with a node in the vicinity of the fuel injector. Since the ASPAC controller sets a relative phase based on observed instability suppression, the phase difference between $P_{3}$ and $P_{4}$ should not negatively impact the controller. Based on these results, it was decided to attempt to repeat some of the earlier shown results, but instead using $P_{3}$ as the feedback sensor to the ASPAC controller.

Figure 13 shows a combustion instability control result using $P_{3 \text { DynA }}$ as feedback and modulating fuel through the main stage injector. For consistency with the presentation of earlier results, $P_{4 \mathrm{DynDn}}$ is shown as the "instability pressure" even though $P_{3 \text { DynA }}$ was used as the controller feedback. As shown in the spectral plots on the left, when the controller is on, the amplitude of the pressure oscillations at the instability frequency is reduced by roughly 85 percent (from 0.43 to $0.06 \mathrm{psi}$ ) from its uncontrolled value. The time history plot on the right shows a decrease in the peak-to-peak pressure oscillations from about 2.0 psi to about 0.8 psi. Note that the uncontrolled peak pressure here is smaller than in results shown earlier due to the continued decrease in instability amplitude versus time discussed earlier. This was considered to be a promising demonstration of the feasibility of using $P_{3}$ for controller feedback.

However, it should be noted that how well the pressure oscillations at $P_{3}$ represent the instability pressure oscillations inside the combustor, and thus these results, may be configuration dependent. Further investigations with other configurations are planned. 

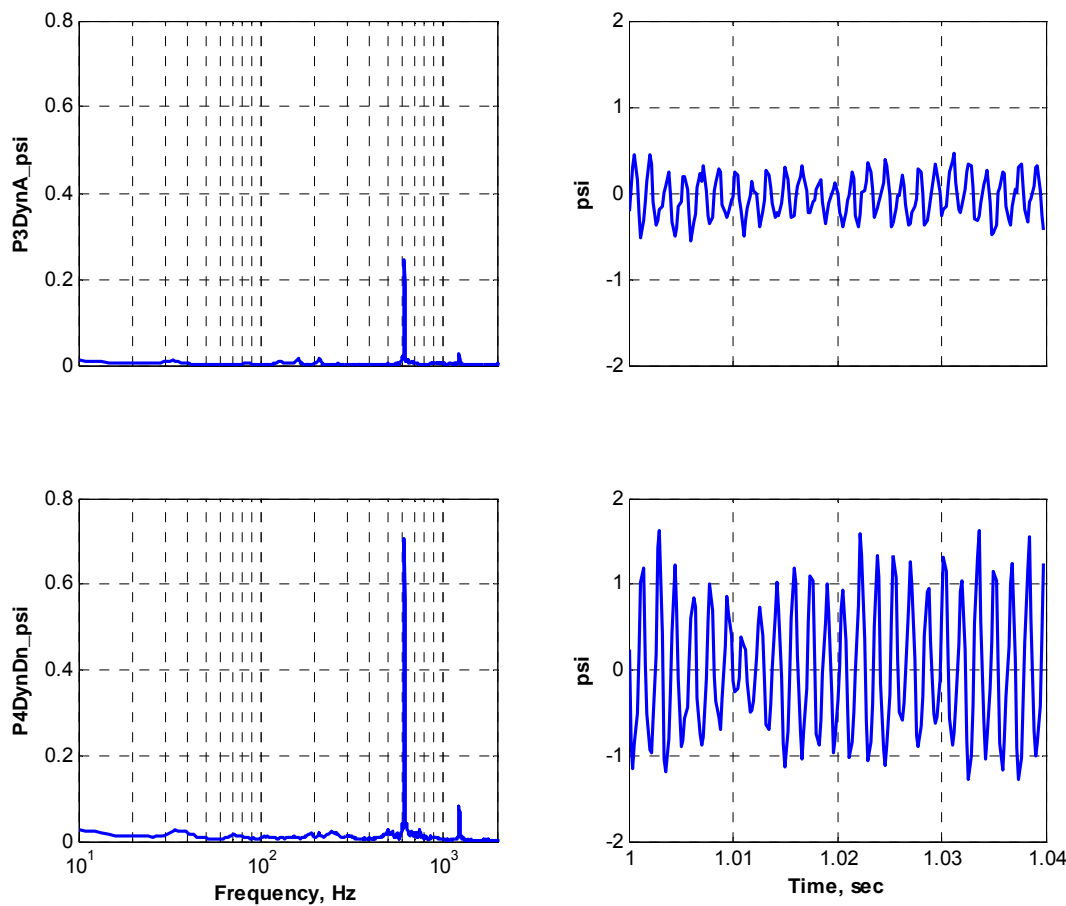

Figure 12.-Comparison of the measured pressure oscillations upstream of the combustor $\left(P_{3 \mathrm{DynA}}\right)$ and inside the combustor $\left(P_{4 \mathrm{DynDn}}\right)$ shows that the combustion instability pressure oscillations can be sensed in the lower temperature environment upstream of the combustor.
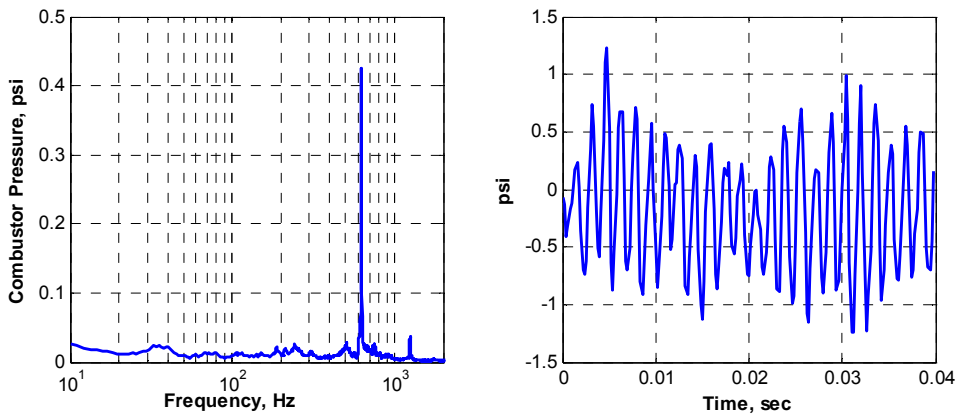

a) Without control
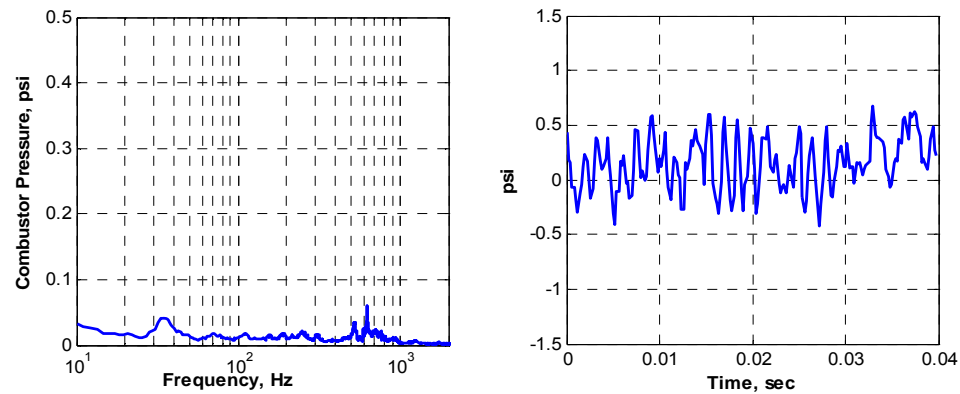

b) With control

Figure 13.-Combustor pressure amplitude spectrum (left) and time history (right) shows the combustion thermoacoustic instability being suppressed by the application of closed-loop control using combustor inlet pressure, $P_{3 \mathrm{DynA}}$, as controller feedback. 


\section{Combustion Instability Control Using Pilot Fuel Injector Modulation}

The high-frequency fuel valve was also installed in the combustor pilot fuel line, which typically carries 10 to 20 percent of the overall combustor fuel flow. The valve installation was very similar to that for the main stage fuel injector. There was slightly less fuel line length, approximately 25 in., between the fuel valve and the fuel injector tip than with the main stage injector. Open-loop, sinusoidal valve command variations were again provided to the valve to observe the response of combustor pressure to the pilot fuel injector perturbations. As with the main stage fuel injector, the commanded frequency and voltage level to the valve were varied and combustor pressure $P_{4 \mathrm{DynDn}}$ monitored. Fixed frequency and sweep frequency perturbations of the valve showed very little response in the combustor pressure. Unlike with the main stage fuel injector modulations, no response was seen in the spectral data at the perturbation frequency. Further, there was no apparent interaction with the instability at frequencies near the instability frequency. There was also very little response in the valve exit pressure to the valve perturbations, further indicating small, if any, fuel flow perturbations into the combustor. This essentially validated the suspicions from dynamic characterization testing of the valve prior to combustion testing that the valve, designed for large Flow Number applications, would have difficulty modulating the flow through a small, pilot fuel injector (Ref. 25). It's possible that even large pilot fuel modulations would be ineffective at instability suppression, although this scenario could not be investigated. Several optimizations of the fuel feed line and valve configuration were attempted with little improvement in the response. None-the-less, it was decided to attempt closed-loop control with the ASPAC controller modulating the pilot fuel. Unfortunately, as described earlier, the combustor instability behavior continued to become harder to elicit, and the FAR required to get an instability to occur exceeded the safe operational limits of the facility. This combined with schedule pressure from other users of the facility ended this combustion control test cell entry and thus prevented further investigation of combustion instability control using pilot fuel modulation. This remains an important future objective.

\section{Closed-Loop Combustor Data for Development of Combustion Control Simulations}

The last research objective was to obtain sufficient combustion instability control data to allow extension of the previously described combustion instability simulation to include closed-loop control. Unfortunately, as described earlier, the instability behavior of the combustor was changing from run to run. As a result, closed-loop instability control results were only obtained at a single operating condition. Further, for this condition, the combustor was being operated differently than in the 2006 testing. Most notably, the FAR was higher and the injector $\Delta P / P$ lower than in any previous testing. Even without control applied, this requires some investigation on how the Sectored 1-D simulation of the combustion instability described in Reference 23 can be updated to capture this new behavior. When/if the simulation is suitably updated to capture the uncontrolled combustor instability behavior, the next effort would be to incorporate the ASPAC controller and try to match the controlled behavior. This is the subject of ongoing work and is not reported on further in this paper.

\section{Concluding Remarks}

Lean combustion concepts for aircraft engine combustors are prone to combustion instabilities. Mitigation of instabilities is an enabling technology for these low-emissions combustors. Active control of combustion instability has been demonstrated on a prototype low-emissions aircraft engine combustor installed in the NASA Glenn CE-5 flametube rig. Dynamic pressure sensors provided the feedback signal for control. A high-frequency fuel modulation valve perturbed the fuel into the combustor. The NASA GRC-developed Adaptive Sliding Phasor Averaged Control (ASPAC) algorithm, utilizing a highfrequency fuel modulation valve, was able to detect and suppress a thermoacoustic combustion instability occurring in the prototype combustor. The ASPAC algorithm determines the frequency at which the instability occurs and modulates the fuel at a phase that interferes with the instability. The phase is 
constantly adapted in order to maintain control as conditions in the combustor change. It was also demonstrated that the controller can prevent the instability from occurring while combustor operation was transitioning from a stable to a normally unstable, high-power condition, thus enabling the high-power operation. A pressure sensor inside the combustor was initially used for feedback. A pressure sensor in the less-harsh environment upstream of the combustor was also able to sense combustion instability inside the combustor and was successfully used as a feedback sensor for the controller. Successful instability control was demonstration with the controller modulating the fuel to the combustor's main stage fuel injector. Testing to demonstrate instability control with the controller modulating the fuel to the combustor's pilot fuel injector was investigated, but was unsuccessful due to inadequate fuel modulation strength. Future plans are to extend an existing simulation of the uncontrolled combustion instability to include the controlled case. Future work is also planned to develop fuel actuators sized for pilot injectors and to apply combustion instability control technologies via pilot fuel modulation to increasingly advanced lean-burn combustors.

\section{References}

1. Lefebvre, A.H.: "Gas Turbine Combustion," $2^{\text {nd }}$ edition, Taylor \& Francis, 1999.

2. Zinn, B.T.; and Lieuwen, T.C.: "Combustion Instabilities: Basic Concepts," Combustion Instabilities in Gas Turbine Engines: Operational Experience, Fundamental Mechanisms, and Modeling, edited by T. Lieuwen and V. Yang, Progress in Astronautics and Aeronautics, AIAA, Reston, VA, 2005, Chap 1, pp. 3-26.

3. Mongia, H.; Held, T.; Hsiao, G; Pandalai, R.: "Challenges and Progress in Controlling Dynamics in Gas Turbine Combustors," Journal of Propulsion and Power, Vol. 19, No. 5, p. 822-829, SeptemberOctober 2003.

4. Lieuwen, T.C., and Yang, V., Combustion Instabilities in Gas Turbine Engines: Operational Experience, Fundamental Mechanisms, and Modeling, Progress in Astronautics and Aeronautics, AIAA, Reston, VA, 2005, Chaps. 2-8.

5. Schadow, K.; Yang, V., Culick, F.; Rosfjord, T.; Sturgess, G.; Zinn, B.: “Active Combustion Control for Propulsion Systems," AGARD Report 820, September 1997.

6. Zinn, B.T.; Neumeier, Y.: "An Overview of Active Control of Combustion Instabilities," AIAA Paper 97-0461, January 1997.

7. McManus, K.R.; Magill, J.C.; Miller, M.F.; Allen, M.G.: "Closed-Loop System for Stability Control in Gas Turbine Combustors," AIAA Paper 97-0463, January 1997.

8. Annaswamy, A.M.; El Rifai, O.M.; Fleifil, M.; Hathout, J.P.; Ghoniem, A.F.: "A Model-based Self-tuning Controller for Thermoacoustic Instability," in Combustion Science and Tech., Vol. 135, pp. 213-240, 1998.

9. Hibshman, J.R.; Cohen, J.M.; Banaszuk, A.; Anderson, T.J.; Alholm, H.A.: "Active Control of Combustion Instability in a Liquid-Fueled Sector Combustor," International Gas Turbine \& Aeroengine Congress and Exhibition, June 1999. ASME Paper 99-GT-215.

10. Allgood, D.; Campos-Delgado, D.U.; Acharya, S.; and Zhoo, K.: "Acoustic Control of Thermoacoustic Instabilities Using Experimental Model-Based Controllers," Proceedings of ASME Turbo Expo, New Orleans, LA, 2001.

11. Johnson, C.E.; Neumeier, Y.; Nuemaier, M.; Zinn, B.T.: "Demonstration of Active Control of Combustion Instabilities on a Full-Scale Gas Turbine Combustor," Proceedings of ASME Turbo Expo, New Orleans, LA, 2001.

12. Kiel, B.: "Review of Advances in Combustion Control, Actuation, Sensing, Modeling and Related Technologies for Air Breathing Gas Turbines," 39th Aerospace Sciences Meeting and Exhibit, Reno NV, AIAA-2001-0481, January 2001.

13. Barooah, P.; Anderson, T.J.; and Cohen, J.M.: "Active Combustion Instability Control with Spinning Valve Actuator," ASME Turbo Expo 2002, Amsterdam, The Netherlands. ASME Paper GT-200230042, June 2002. 
14. Park, S.; Ghosh, A.; Diao, Q.; and Ye, K.H.: "Optimizing Combustion Instability Suppression Using Secondary Fuel Injection," 47th Joint Propulsion Conference \& Exhibit, San Diego, CA, AIAA-20115627, August, 2011.

15. Goeke, J.L., and Overman, N.T.: "Active Combustion Control System Rig Testing," 46th Joint Propulsion Conference \& Exhibit, Nashville, TN, AIAA-2010-6865, July 2010.

16. DeLaat, J.C.; Chang, C.T.: "Active Control of High Frequency Combustion Instability in Aircraft Gas-Turbine Engines," 16th International Symposium on Airbreathing Engines, Cleveland, $\mathrm{OH}$, ISABE-2003-1054, NASA/TM-2003-212611, September 2003.

17. Le, D.K.; DeLaat, J.C.; Chang, C.T.; Vrnak, D.R.: "Model-Based Self-Tuning Multiscale Method for Combustion Control," 41 st Joint Propulsion Conference and Exhibit, Tucson, Arizona, AIAA-20053593, July 2005.

18. Kopasakis, G.; DeLaat, J.C.; Chang, C.T.: "Adaptive Instability Suppression Controls Method For Aircraft Gas Turbine Engine Combustors," Journal of Propulsion and Power, Vol. 25, No. 3, MayJune 2009, pp. 618-627.

19. Cohen, J.M.; Proscia, W; and DeLaat, J.C.: "Characterization and Control of Aeroengine Combustion Instability: Pratt \& Whitney and NASA Experience," Combustion Instabilities in Gas Turbine Engines, Operational Experience, Fundamental Mechanisms, and Modeling, Progress in Astronautics and Aeronautics series, AIAA, Reston, VA, 2005, Chap 6, p. 113-145.

20. Okojie, R.S.; DeLaat, J.C.; Saus, J.R.: "SiC Pressure Sensor for Detection of Combustor Thermoacoustic Instabilities," Proceedings of the 13th International Conference on Solid-State Sensors, Actuators and Microsystems, Seoul, Korea, Volume 1, p. 470-473, June 2005.

21. Paxson, D.: "A Sectored-One-Dimensional Model for Simulating Combustion Instabilities in Premix Combustors," 38th Aerospace Sciences Meeting \& Exhibit. AIAA-2000-0313, NASA TM-1999209771, January 2000.

22. Tacina, R.; Wey, C.; Laing, P.; Mansour, A.: “A Low NOx Lean-Direct Injection, Multipoint Integrated Module Combustor Concept for Advanced Aircraft Gas Turbines," NASA/TM-2002211347, April 2002.

23. DeLaat, J.C.; Paxson, D.E.: "Characterization and Simulation of the Thermoacoustic Instability Behavior of an Advanced, Low Emissions Combustor Prototype," 44th Joint Propulsion Conference and Exhibit, Hartford, Connecticut, AIAA-2008-4878, NASA/TM-2008-215291, July 2008.

24. Saus, J.R.; Chang, C.T.; DeLaat, J.C.; Vrnak, D.R.: "Design and Implementation of a Characterization Test Rig for Evaluating High Bandwidth Liquid Fuel Flow Modulators," Presented at the 45th Joint Propulsion Conference and Exhibit, Denver, CO, AIAA-2009-4886, NASA/TM-2010-216105, August 2009.

25. Saus, J.R.; Chang, C.T.; DeLaat, J.C.; and Vrnak, D.R.: "Performance Evaluation of a High Bandwidth Liquid Fuel Modulation Valve for Active Combustion Control," 50th AIAA Aerospace Sciences Meeting, Nashville, TN, AIAA-2012-1274, January 2012. 


\begin{tabular}{|c|c|c|}
\hline \multicolumn{2}{|c|}{ REPORT DOCUMENTATION PAGE } & $\begin{array}{l}\text { Form Approved } \\
\text { OMB No. 0704-0188 }\end{array}$ \\
\hline \multicolumn{3}{|c|}{$\begin{array}{l}\text { The public reporting burden for this collection of information is estimated to average } 1 \text { hour per response, including the time for reviewing instructions, searching existing data sources, gathering and maintaining the } \\
\text { data needed, and completing and reviewing the collection of information. Send comments regarding this burden estimate or any other aspect of this collection of information, including suggestions for reducing this } \\
\text { burden, to Department of Defense, Washington Headquarters Services, Directorate for Information Operations and Reports (0704-0188), 1215 Jefferson Davis Highway, Suite } 1204 \text {, Arlington, VA } 22222-2302 \text {. } \\
\text { Respondents should be aware that notwithstanding any other provision of law, no person shall be subject to any penalty for failing to comply with a collection of information if it does not display a currently valid OMB } \\
\text { control number. } \\
\text { PLEASE DO NOT RETURN YOUR FORM TO THE ABOVE ADDRESS. }\end{array}$} \\
\hline $\begin{array}{l}\text { 1. REPORT DATE (DD-MM-YYYY) } \\
01-07-2012\end{array}$ & $\begin{array}{l}\text { 2. REPORT TYPE } \\
\text { Technical Memorandum }\end{array}$ & 3. DATES COVERED (From - To) \\
\hline \multirow{3}{*}{\multicolumn{2}{|c|}{$\begin{array}{l}\text { 4. TITLE AND SUBTITLE } \\
\text { Active Combustion Control for Aircraft Gas-Turbine Engines-Experimental Results for an } \\
\text { Advanced, Low-Emissions Combustor Prototype }\end{array}$}} & 5a. CONTRACT NUMBER \\
\hline & & 5b. GRANT NUMBER \\
\hline & & 5c. PROGRAM ELEMENT NUMBER \\
\hline \multirow{3}{*}{\multicolumn{2}{|c|}{$\begin{array}{l}\text { 6. AUTHOR(S) } \\
\text { DeLaat, John, C.; Kopasakis, George; Saus, Joseph, R.; Chang, Clarence, T.; Wey, Changlie }\end{array}$}} & 5d. PROJECT NUMBER \\
\hline & & 5e. TASK NUMBER \\
\hline & & $\begin{array}{l}\text { 5f. WORK UNIT NUMBER } \\
\text { WBS 984754.02.07.03.19.04 }\end{array}$ \\
\hline \multicolumn{2}{|c|}{$\begin{array}{l}\text { 7. PERFORMING ORGANIZATION NAME(S) AND ADDRESS(ES) } \\
\text { National Aeronautics and Space Administration } \\
\text { John H. Glenn Research Center at Lewis Field } \\
\text { Cleveland, Ohio 44135-3191 }\end{array}$} & $\begin{array}{l}\text { 8. PERFORMING ORGANIZATION } \\
\text { REPORT NUMBER } \\
\text { E-18205 }\end{array}$ \\
\hline \multirow{2}{*}{\multicolumn{2}{|c|}{$\begin{array}{l}\text { 9. SPONSORING/MONITORING AGENCY NAME(S) AND ADDRESS(ES) } \\
\text { National Aeronautics and Space Administration } \\
\text { Washington, DC 20546-0001 }\end{array}$}} & $\begin{array}{l}\text { 10. SPONSORING/MONITOR'S } \\
\text { ACRONYM(S) } \\
\text { NASA }\end{array}$ \\
\hline & & $\begin{array}{l}\text { 11. SPONSORING/MONITORING } \\
\text { REPORT NUMBER } \\
\text { NASA/TM-2012-217617 }\end{array}$ \\
\hline
\end{tabular}

\section{DISTRIBUTION/AVAILABILITY STATEMENT}

Unclassified-Unlimited

Subject Category: 07

Available electronically at http://www.sti.nasa.gov

This publication is available from the NASA Center for AeroSpace Information, 443-757-5802

\section{SUPPLEMENTARY NOTES}

\section{ABSTRACT}

Lean combustion concepts for aircraft engine combustors are prone to combustion instabilities. Mitigation of instabilities is an enabling technology for these low-emissions

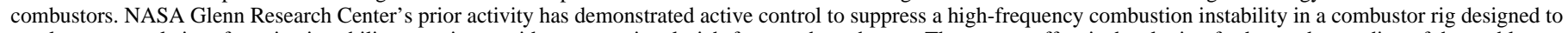
emulate an actual aircraft engine instability experience with a conventional, rich-front-end combustor. The current effort is developing further understanding of the problem specifically as applied to future lean-burning, very low-emissions combustors. A prototype advanced, low-emissions aircraft engine combustor with a combustion instability

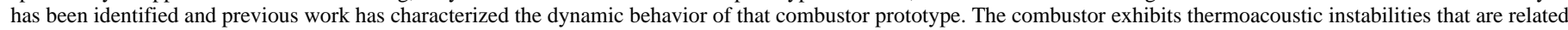

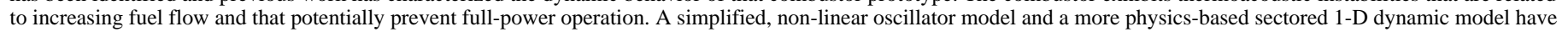
been developed to capture the combustor prototype's instability behavior. Utilizing these models, the NASA Adaptive Sliding Phasor Average Control (ASPAC) instability control method has been updated for the low-emissions combustor prototype. Active combustion instability suppression using the ASPAC control method has been demonstrated experimentally with this combustor prototype in a NASA combustion test cell operating at engine pressures, temperatures, and flows. A high-frequency fuel valve was utilized to perturb the combustor fuel flow. Successful instability suppression was shown using a dynamic pressure sensor in the combustor for controller feedback.

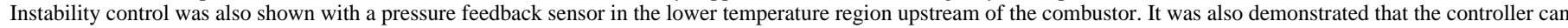
prevent the instability from occurring while combustor operation was transitioning from a stable, low-power condition to a normally unstable high-power condition, thus enabling the high-power condition.

\section{SUBJECT TERMS}

Aircraft engines; Combustion stability; Combustion control; Engine control

\begin{tabular}{|c|c|c|c|c|}
\hline \multicolumn{3}{|c|}{ 16. SECURITY CLASSIFICATION OF: } & \multirow{2}{*}{$\begin{array}{l}\text { 17. LIMITATION OF } \\
\text { ABSTRACT } \\
\text { UU }\end{array}$} & \multirow{2}{*}{$\begin{array}{l}\text { 18. NUMBER } \\
\text { OF } \\
\text { PAGES } \\
25\end{array}$} \\
\hline $\begin{array}{l}\text { a. REPORT } \\
\text { U }\end{array}$ & $\begin{array}{l}\text { b. ABSTRACT } \\
\mathrm{U}\end{array}$ & $\begin{array}{l}\text { c. THIS } \\
\text { PAGE } \\
\text { U }\end{array}$ & & \\
\hline
\end{tabular}

19a. NAME OF RESPONSIBLE PERSON STI Help Desk (email:help@sti.nasa.gov) 19b. TELEPHONE NUMBER (include area code) 443-757-5802 
